\title{
Mycoplasma ellychniae sp. nov., a Sterol-Requiring Mollicute from the Firefly Beetle Ellychnia corrusca
}

\author{
JOSEPH G. TULLY, ${ }^{1 *}$ DAVID L. ROSE, ${ }^{1}$ KEVIN J. HACKETT,${ }^{2}$ ROBERT F. WHITCOMB, ${ }^{2}$ PATRICIA CARLE, ${ }^{3}$ \\ JOSEPH M. BOVÉ, ${ }^{3}$ DAVID E. COLFLESH, ${ }^{4}$ AND DAVID L. WILLIAMSON ${ }^{4}$ \\ Mycoplasma Section, Laboratory of Molecular Microbiology, National Institute of Allergy and Infectious Diseases, \\ Frederick Cancer Research Facility, Frederick, Maryland $21701^{1}$; Insect Pathology Laboratory, United States \\ Department of Agriculture, Beltsville, Maryland 207052; Laboratoire de Biologie Cellulaire et Moléculaire, \\ Institut Nationale de Recherche Agronomique, Pont-de-la-Maye, France ${ }^{3}$; and Department of \\ Anatomical Sciences, State University of New York, Stony Brook, New York $11794^{4}$
}

\begin{abstract}
Strain ELCN-1 ${ }^{\mathrm{T}}$ ( $\mathrm{T}=$ type strain), which was isolated from the hemolymph of the firefly beetle Ellychnia corrusca (Coleoptera:Lampyridae) in Maryland, was shown to be a sterol-requiring mollicute. Electron and dark-field microscopy showed that the organism consisted of small, nonhelical, nonmotile, pleomorphic coccoid cells. Individual cells were surrounded by a single cytoplasmic membrane, but no evidence of a cell wall was observed. The organism grew well in SP-4 broth medium containing fetal bovine serum, but failed to grow in formulations containing horse serum or bovine serum fraction supplements. Growth on solid media occurred only when agar cultures were incubated aerobically or in an atmosphere containing $5 \%$ carbon dioxide. Strain ELCN-1 ${ }^{\mathrm{T}}$ catabolized glucose but did not hydrolyze arginine or urea. The optimum temperature for growth was $30^{\circ} \mathrm{C}$, while multiplication occurred over a temperature range of 18 to $32^{\circ} \mathrm{C}$. Growth was not observed at $37^{\circ} \mathrm{C}$. The genome of strain ELCN-1 ${ }^{\mathrm{T}}$ was determined to be about 585 megadaltons. The guanine-plus-cytosine content of the deoxyribonucleic acid was found to be $27.5 \mathrm{~mol} \%$. This organism was serologically unrelated to the type strains of previously described Mycoplasma species and to 18 other unclassified sterol-requiring isolates cultivated from various animal, plant, or insect sources. This is the first documented insect-derived species in the genus Mycoplasma. Strain ELCN-1 (= ATCC 43707) is the type strain of Mycoplasma ellychniae sp. nov.
\end{abstract}

The presence of wall-less procaryotes (class Mollicutes) in the microbial flora of insects and other arthropods first became a recognized possibility with the 1967 discovery of mycoplasma-like organisms in plants infected with the leafhopper-borne mulberry dwarf disease agent (12). Although wall-less procaryotes have yet to be cultivated axenically from infected vectors or plants with mulberry disease or from any of the more than 300 other known mycoplasma-like organism-associated diseases, infections caused by mycoplasma-like organisms have been associated consistently with specific insect vectors (22). By the early 1970s, two other important observations provided substantial evidence of insect association with mollicutes. Cultivation and characterization of the first helical mollicute (Spiroplasma citri) from stubborn-diseased citrus plants $(9,26)$ had occurred, and the organism was shown to be transmissible to citrus by experimentally infected leafhoppers (11). In addition, the then uncultivated corn stunt spiroplasma was shown to be transmitted by leafhoppers (see review in reference 34). Although the role of insects as vectors of plant-pathogenic spiroplasmas was established in these studies, it remained for Clark and colleagues to demonstrate that a diversity of insects harbored a extraordinarly rich spiroplasma flora (5, 18 ).

The association of other mollicutes with insects followed the discovery of spiroplasmas in these hosts. The presence of nonhelical mollicutes on plant surfaces was first well documented in $1979(13,23)$, when organisms with the general features of both Acholeplasma and Mycoplasma species were isolated from vegetative and floral plant parts. Some of these isolates were serologically related to known

\footnotetext{
* Corresponding author.
}

acholeplasmas (Acholeplasma axanthum, Acholeplasma oc$u l i)$, while others were subsequently found to represent a new species (e.g., Acholeplasma florum) clearly associated with and known only from plant hosts (21). The occurrence of acholeplasmas in insects was established when Clark and colleagues (6) reported the isolation of sterol-nonrequiring mollicutes from the guts of five different insect species. Some of these isolates, including representatives from a deerfly (Chrysops discalis) and a vespid wasp (Monobia quadridens) and strains recovered from other insects (32), were identified as A. florum. These observations confirmed a direct ecological link between acholeplasmas on surfaces of plants or flowers and an insect reservoir. More recently, other acholeplasmas isolated from insect guts have turned out to be new species (e.g., Acholeplasma entomophilum) (31) or putative new species (30).

The possibility that sterol-requiring Mycoplasma species may, like acholeplasmas, be specifically associated with insect-plant interactions has been suspected but not clearly established previously (30). A number of putative new species in the genus Mycoplasma have been cultivated from plant sources and are in various stages of characterization (30). Recently, 30 mollicutes isolated by Clark and colleagues from the guts or hemolymphs of a wide range of insect species were examined (32); 5 of these strains were found to be sterol-requiring, nonhelical mollicutes. In this paper we describe the detailed taxonomic features of strain ELCN $-1^{\mathrm{T}}$ ( $\mathrm{T}=$ type strain), which was isolated from hemolymph of the firefly beetle Ellychnia corrusca, and propose that this organism be assigned to the genus Mycoplasma. This is the first species in this genus to be clearly shown to be specifically associated with insects. 
TABLE 1. Mollicute strains and antisera tested

\begin{tabular}{|c|c|}
\hline Strain & Source" \\
\hline \multicolumn{2}{|l|}{ Mycoplasma agalactiae $\mathrm{PG}^{\mathrm{T}}$. } \\
\hline Mycoplasma alkalescens $\mathrm{D} 12^{\mathrm{T}}$ & $. . \mathrm{MS}-\mathrm{LMI}$ \\
\hline Mycoplasma alvi Ilsley ${ }^{\mathrm{T}} \ldots \ldots \ldots$. & \\
\hline Mycoplasma anatis $1340^{\mathrm{T}}$. &. $\mathrm{NIH}$ \\
\hline Mycoplasma anseris $1219^{\mathrm{T}}$ & \\
\hline Mycoplasma arginini $\mathrm{G} 230^{\mathrm{T}}$ & \\
\hline Mycoplasma arthritidis $\mathrm{PG}^{\mathrm{T}}$. & ..NIH \\
\hline Mycoplasma bovigenitalium PG11 ${ }^{\mathrm{T}}$. &.. $\mathrm{NIH}$ \\
\hline dycoplasma bovirhinis $\mathrm{PG}^{4} 3^{\mathrm{T}}$. & ..NIH \\
\hline Mycoplasma bovis Donetta ${ }^{\mathrm{T}}$ & \\
\hline Mycoplasma bovoculi M165/C & ..MS-LM \\
\hline Mycoplasma buccale $\mathrm{CH} 20247^{\mathrm{T}}$ &. NIH \\
\hline Mycoplasma californicum ST-6 ${ }^{\mathrm{T}}$. & ..MS-LMM \\
\hline Mycoplasma canadense $275 \mathrm{C}^{\mathrm{T}}$.. & \\
\hline Mycoplasma canis & \\
\hline Mycoplasma capric & -LMI \\
\hline oplasma ca & \\
\hline oplasma ca & \\
\hline Mycoplasma c & \\
\hline Mycoplasn & \\
\hline plasn & Ml \\
\hline $\begin{array}{l}\text { Mycoplasm } \\
\text { Mycoplasm }\end{array}$ & M) \\
\hline $\begin{array}{l}\text { Mycoplasm } \\
\text { Mycoplasm }\end{array}$ & MI \\
\hline $\begin{array}{l}\text { Mycoplasn } \\
\text { Mycoplasn }\end{array}$ & \\
\hline $\begin{array}{l}\text { ae } \mathrm{HRC}^{2} 81^{\mathrm{T}} \\
\mathrm{H}^{\mathrm{T}} \ldots \ldots \ldots \ldots \ldots . . . . .\end{array}$ & \\
\hline Mycoplasma cynos & MI \\
\hline Mycoplasma dis & .MS- \\
\hline Mycoplasma edwa & MS \\
\hline Mycoplasma equig & MS-LMN \\
\hline Mycoplasma equirh & MS-LMN \\
\hline plast & . M \\
\hline Mycoplasma $f$ &. $\mathrm{~N}$ \\
\hline Mycoplasma felifaucium $\mathrm{PU}^{\mathrm{T}}$. & LMM \\
\hline Mycoplasma feliminutum $\mathrm{Ben}^{\mathrm{T}}$. & .1 \\
\hline Mycoplasma felis & .MS-LMI \\
\hline Mycoplasma ferr & .NIH \\
\hline Mycoplasma flo & MS-LMM \\
\hline Mycoplasma galline & -LMI \\
\hline ycoplasma gallina & \\
\hline ycoplasma gallise & . NIH \\
\hline lasma & MN \\
\hline las & . \\
\hline ycoplasma g & MN \\
\hline ycoplasma glycophilum $486^{\mathrm{T}}$ & MS-LMN \\
\hline ycoplasma hominis $\mathrm{PG} 21^{\mathrm{T}}$ & $\mathrm{N}$ \\
\hline $\operatorname{lag}$ & MM \\
\hline$h$ & .MS-LMN \\
\hline ycoplasma hy & \\
\hline lycoplasma hyc & MS-LMN \\
\hline plasma ine & NIH \\
\hline lasma ic & MS-LMM \\
\hline ycoplasma lipofaci & MS-LMM \\
\hline ycoplasma lipo & \\
\hline ycoplasma $n$ & NIH \\
\hline lasmar & \\
\hline lasn & MS-LMM \\
\hline lasma & MN \\
\hline plasma $\mathrm{r}$ & MN \\
\hline lasma & MM \\
\hline ycoplasma mustel & MM \\
\hline Mycoplasma mycoides $\mathrm{s}$ & MS-LMM \\
\hline ycoplasma mycoides subsp. cap & MS-LMM \\
\hline ycoplasma neurolyticu & NIH \\
\hline MH5408 & MS-LMM \\
\hline & \\
\hline plasma ovt & MM \\
\hline tram & IS-LMN \\
\hline
\end{tabular}

Continued
TABLE 1-Continued

\begin{tabular}{|c|c|}
\hline Strain & Source $^{a}$ \\
\hline Mycoplasma pneumoniae $\mathrm{FH}^{\mathrm{T}}$ & ..NIF \\
\hline Mycoplasma primatum $\mathrm{HRC} 292^{\mathrm{T}}$. & .MS-LMM \\
\hline Mycoplasma pullorum $\mathrm{CKK}^{\mathrm{T}} \ldots .$. & ..MS-LMM \\
\hline Mycoplasma pulmonis PG34T &. NIH \\
\hline Mycoplasma putrefaciens $\mathrm{KS}-1^{\mathrm{T}}$. & .MS-LMM \\
\hline Mycoplasma salivarium $\mathrm{PG}^{\mathrm{T}}{ }^{\mathrm{T}}$. &. $\mathrm{NIH}$ \\
\hline Mycoplasma spumans $\mathrm{PG} 13^{\mathrm{T}}$. &. $\mathrm{NIH}$ \\
\hline Mycoplasma sualvi Mayfield $\mathrm{B}^{\mathrm{T}}$ & MS-LMM \\
\hline Mycoplasma subdolum $\mathrm{TB}^{\mathrm{T}}$. & MS-LMM \\
\hline Mycoplasma synoviae WVU $1853^{\mathrm{T}}$ & MS-LMM \\
\hline Mycoplasma testudinis $01008^{\mathrm{T}}$. & MS-LMM \\
\hline Mycoplasma verecundum $107^{\mathrm{T}}$. & MS-LMM \\
\hline Mycoplasma sp. strain California calf (joint) ${ }^{b}$. & MS-LMM \\
\hline Mycoplasma sp. strain B5P (bovine joint) .. & MS-LMM \\
\hline Mycoplasma sp. strain melaleuca (plant) ... & .MS-LMM \\
\hline Mycoplasma sp. strain $831-\mathrm{C} 4$ (lettuce) ........ & .MS-LMM \\
\hline Mycoplasma sp. strain PPAV (apple) & .MS-LMM \\
\hline Mycoplasma sp. strain F38 (caprine lung) . & .MS-LMM \\
\hline Mycoplasma sp. strain M7806 (human abscess). & .MS-LMM \\
\hline Mycoplasma sp. strain 3306 (ovine genitalia) ... & MS-LMM \\
\hline Mycoplasma sp. strain M2851 (equine uterus). & MS-LMM \\
\hline Mycoplasma sp. strain S5251 (seal lung) ... & MS-LMM \\
\hline Mycoplasma sp. strain HRC291 (primate throat) & MS-LMM \\
\hline Mycoplasma sp & MS-LMM \\
\hline Mycoplasma sp. strain G145 (goat leg).... & .MS-LMM \\
\hline Mycoplasma sp. strain B689 (dog throat) ...... & MS-LMM \\
\hline Mycoplasma sp. strain GM257A (caprine ear). & .MS-LMM \\
\hline Mycoplasma sp. strain PYAN-1 (firefly gut)..... & .MS-LMM \\
\hline Mycoplasma sp & MM \\
\hline Mycoplasma sp. strain PIPN-2 (firefly gut). & .MS-LMM \\
\hline Acholeplasma axanthum $\mathrm{S} 743^{\mathrm{T}}$ & .MS-LMM \\
\hline Acholeplasma entomophilum $\mathrm{TAC}^{\mathrm{T}}$ & .MS-LMM \\
\hline Acholeplasma equifetale $\mathrm{C} 112^{\mathrm{T}}$. & .MS-LMM \\
\hline Acholeplasma florum $\mathrm{L1}^{\mathrm{T}} \ldots$ & .MS-LMM \\
\hline Acholeplasma granularum BTS39 & .MS-LMM \\
\hline Acholeplasma hippikon $\mathrm{Cl}^{\mathrm{T}}$ & MS-LMM \\
\hline Acholeplasma laidlawii $\mathrm{PG8}^{\mathrm{T}}$ & MS-LMM \\
\hline Acholeplasma modicum $\mathrm{PG}_{4} 9^{\mathrm{T}}$ & .MS-LMM \\
\hline Acholeplasma morum $72-043^{\mathrm{T}}$. & MS-LMM \\
\hline Acholeplasma oculi $19 \mathrm{~L}^{\mathrm{T}} \ldots \ldots$. & MS-LMM \\
\hline Acholeplasma parvum $\mathrm{H}_{2} 3 \mathrm{M}^{\mathrm{T}}$. & MS-LMM \\
\hline
\end{tabular}

${ }^{a} \mathrm{NIH}$, National Institutes of Health reference reagent; MS-LMM, reagent prepared by Mycoplasma Section, Laboratory of Molecular Microbiology, National Institute of Allergy and Infectious Diseases, Frederick, Md.

${ }^{b}$ The information in parentheses indicates the source of a strain.

\section{MATERIALS AND METHODS}

Mycoplasma strains. The techniques employed in the primary isolation of mollicutes from insect tissues have been described previously $(20,32)$. Strain ELCN $-1^{\mathrm{T}}$ was isolated and cultivated by T. B. Clark from the hemolymph of an $E$. corrusca firefly beetle collected in Maryland. Preliminary analyses of growth requirements and serological features of this organism have been described previously (32). Strain ELCN $-1^{\mathrm{T}}$ was purified by conventional filtration cloning techniques (28). The type strains of previously described Mycoplasma species, as well as a large cluster of currently unclassified, nonhelical, sterol-requiring mollicutes of diverse animal, plant, and insect origins, were also used in various parts of this study (Table 1).

Culture medium and cultivation techniques. Strain ELCN$1^{\mathbf{T}}$ was grown in primary culture on M1D medium (33) at $30^{\circ} \mathrm{C}$, and after three to five early broth passages the organism was lyophilized. For characterization studies, a vial of the dried stock culture was revived and passaged twice in $\mathrm{SP}-4$ broth $(33)$ at $30^{\circ} \mathrm{C}$ before purification procedures were 
undertaken. Following filtration cloning, a triply cloned line was designated strain ELCN-1 ${ }^{\mathrm{T}}$; this strain was used in all subsequent characterization work. Other culture medium formulations used included the following: the Edward formulation of conventional $20 \%$ horse serum mycoplasma broth (14); serum fraction broth containing $1 \%$ bovine serum fraction (29); and serum-free media supplemented with fatty acid mixtures (31). A solid medium of each of these formulations was made by adding $0.8 \%$ Noble agar (Difco Laboratories, Detroit, Mich.). Agar cultures were incubated at $30^{\circ} \mathrm{C}$ either aerobically with $5 \%$ carbon dioxide in a GasPak system (BBL Microbiology Systems, Cockeysville, Md.) or under anaerobic conditions (hydrogen GasPak system).

For measuring the temperature requirements for growth of strain ELCN-1 ${ }^{\mathrm{T}}$, a series of 10 -fold dilutions of the organism in SP-4 broth was prepared. One series of the diluted mycoplasma was incubated at each of six temperatures $(10$, $18,25,30,32$, and $37^{\circ} \mathrm{C}$ ). The relative number of organisms, measured by noting color changes (red to yellow) and turbidity in the highest dilution of SP-4 broth (color-changing units per milliliter), was recorded after incubation for 3 weeks. Early passages of strain ELCN-1 ${ }^{\mathrm{T}}$ were also grown on SP-4 medium devoid of penicillin and other antibiotics for at least five consecutive passages. At each subculture, the organism was plated onto conventional blood agar and incubated aerobically at $37^{\circ} \mathrm{C}$. After 2 to 10 days, the plates were examined for bacterial colonies and evidence of reversion.

Morphological studies. Cells of strain ELCN-1 ${ }^{\mathrm{T}}$ from SP-4 broth cultures in the logarithmic phase were examined by dark-field microscopy, using a magnification of $\times 1,250$. For electron microscopic examination, the organism was grown in approximately $10 \mathrm{ml}$ of broth and pelleted by centrifugation. The cells were then fixed for $2 \mathrm{~h}$ in $3 \%$ glutaraldehyde, postfixed in $1 \%$ osmium tetroxide for $1 \mathrm{~h}$, dehydrated in acetone, embedded in Epon-araldite, sectioned, and stained with $1 \%$ aqueous uranyl acetate and Reynold lead citrate.

Sterol requirement. Sterol requirements for growth were assayed by using a broth culture method, which was slightly modified from the method described previously (25). Cultures were incubated at $30^{\circ} \mathrm{C}$ rather than $37^{\circ} \mathrm{C}$, and protein assays were performed with a Bio-Rad kit (Bio-Rad Laboratories, Richmond, Calif.).

Tests for biological and biochemical properties. The procedures used for demonstrating carbohydrate fermentation and arginine and urea hydrolysis have been described previously (1). Filtration characteristics were measured in SP-4 broth by using techniques described previously (28). The procedures used for the hemadsorption assay (16) and film and spot reaction (15) also have been described previously.

Serological tests. Antiserum to strain ELCN $-1^{\mathrm{T}}$ was raised in rabbits. Hyperimmune antisera to all previously described Mycoplasma species and to 18 other unclassified mycoplasmas (Table 1) came from the reference collection maintained at the National Institute of Allergy and Infectious Diseases laboratory in Frederick, Md. These antisera and strain ELCN $-1^{\mathrm{T}}$ were tested in a standard disk growth inhibition test (8), in which we used SP-4 agar plates and aerobic incubation at $30^{\circ} \mathrm{C}$. In addition, direct plate immunofluorescent tests (17) were performed on strain ELCN $-1^{\mathrm{T}}$ colonies on SP-4 agar medium by using fluorescein-conjugated antisera to the mycoplasmas listed in Table 1 . Finally, disk growth inhibition tests with strain ELCN-1 ${ }^{\mathrm{T}}$ were performed with antisera to the 11 recognized Acholeplasma species (31).

Genomic analysis. Techniques for extraction and purifica-

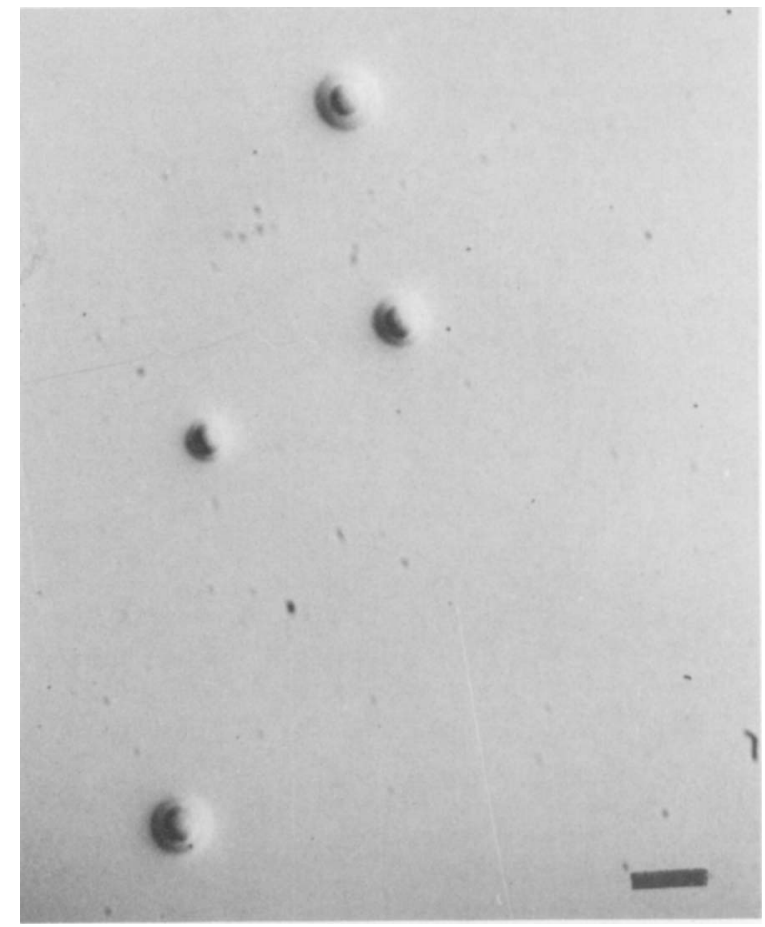

FIG. 1. Colonies of strain ELCN-1 ${ }^{\mathrm{T}}$ on SP-4 agar medium after 3 days of incubation at $30^{\circ} \mathrm{C}$ under aerobic conditions. Bar $=100 \mu \mathrm{m}$.

tion of chromosomal deoxyribonucleic acid (DNA) from mollicutes have been described previously (3). A method for determining genome size by measuring the renaturation kinetics of denatured DNA has also been described previously (2). The guanine-plus-cytosine content of purified DNA from strain ELCN-1 ${ }^{T}$ was assayed by the following three techniques: buoyant density, melting temperature, and high-performance liquid chromatography techniques (4). Purified DNA from $S$. citri (genome, approximately 1,000 megadaltons; base composition, 26 mol\% guanine plus cytosine) was used as a reference DNA in all procedures.

\section{RESULTS AND DISCUSSION}

Cultural and morphological properties. Strain ELCN-1 ${ }^{\mathrm{T}}$ grew only in SP-4 or M1D medium or on solid media prepared from these formulations. No evidence of multiplication occurred in conventional mycoplasma media containing horse serum (Edward formulation) or bovine serum fraction supplements. Growth occurred over a temperature range of 18 to $32^{\circ} \mathrm{C}$, with optimum growth observed at $30^{\circ} \mathrm{C}$. No growth was recorded during a 3 -week period in broth media incubated at 10 or $37^{\circ} \mathrm{C}$. Colonies of strain ELCN $-1^{\mathrm{T}}$ on SP-4 agar exhibited a typical fried-egg morphology (Fig. 1). Growth on solid medium was observed on agar plates incubated aerobically at $30^{\circ} \mathrm{C}$ or in a GasPak system under a carbon dioxide atmosphere. No growth occurred on agar media under anaerobic conditions.

Logarithmic-phase cultures of strain ELCN-1 ${ }^{\mathrm{T}}$ in SP-4 medium examined by dark-field microscopy contained numerous pleomorphic coccoid forms and short branching filaments. No evidence of helical forms was observed, and filamentous elements were nonmotile. The cells of the organism sedimented from broth cultures and examined by electron microscopic techniques were predominately pleo- 


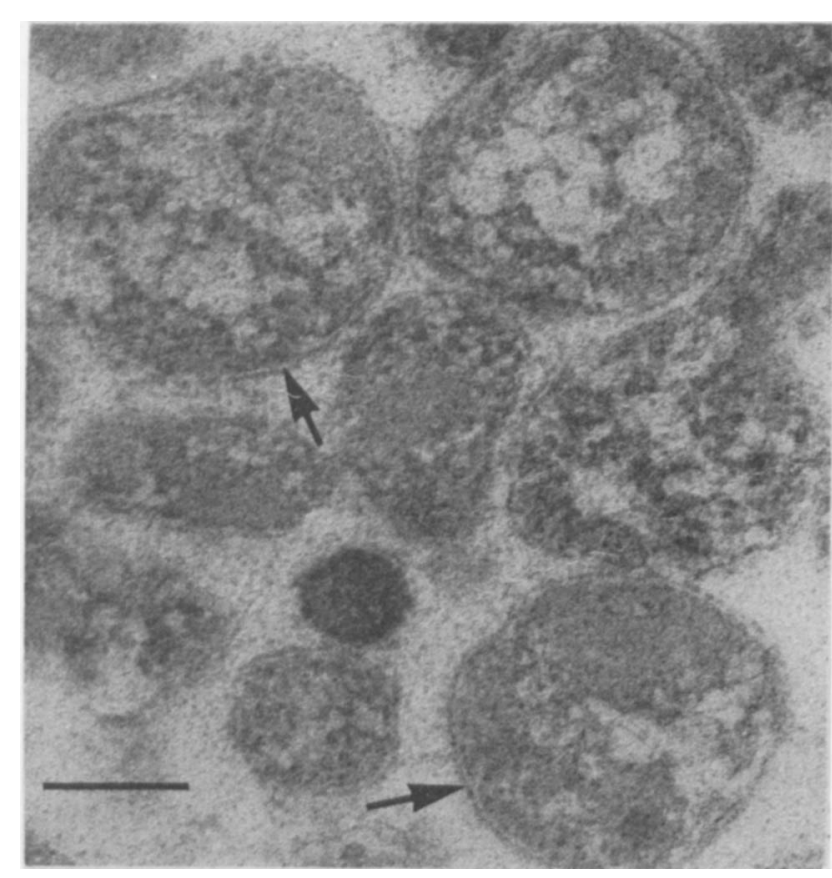

FIG. 2. Electron micrograph of a sectioned and stained cell pellet of strain ELCN-1 ${ }^{\mathrm{T}}$. Sections were stained with $2 \%$ aqueous uranyl acetate and Reynold lead citrate. The arrow indicates the unit membrane. Bar $=100 \mathrm{~nm}$.

morphic coccoid cells (Fig. 2). No evidence of a cell wall was observed in these preparations; representative round cells were about 200 to $300 \mathrm{~nm}$ in diameter and were surrounded by a single cytoplasmic membrane.

Sterol requirement. The response of strain ELCN-1 ${ }^{\mathrm{T}}$ to additions of cholesterol to serum-free SP-4 medium is shown in Table 2. The SP-4 medium control flask (containing serum) appeared to reach maximum growth after 2 days of incubation at $30^{\circ} \mathrm{C}$, and cells were removed by centrifugation for a protein assay. After incubation for 5 days, growth was not apparent in the base broth alone or in base broth containing fatty acid supplements. However, at this time, enhanced growth (measured by increasing levels of protein) was detected when 5 to $20 \mu \mathrm{g}$ of cholesterol per ml was included in the base broth. Similar responses (data not shown) were observed when various amounts (1 to $17 \%$ ) of fetal bovine serum were added to the SP-4 base broth.

Biochemical and biological properties. Strain ELCN-1 ${ }^{\mathrm{T}}$ fermented glucose with the production of acid and a consequent decline in the $\mathrm{pH}$ of the culture medium. No evidence of arginine or urea hydrolysis was observed. Strain ELCN$1^{T}$ did not produce the film and spot reaction, and colonies of the organism on an agar medium did not hemadsorb guinea pig erythrocytes. Passage of broth cultures of strain ELCN$1^{\mathrm{T}}$ through 450 - or $300-\mathrm{nm}$ membrane filters did not reduce the viable cell titer $\left(10^{8}\right.$ color-changing units per $\left.\mathrm{ml}\right)$. The titer of a broth culture filtrate obtained after passage through a $220-\mathrm{nm}$ membrane was reduced about 10 -fold (to $10^{7}$ color-changing units per ml), while the 100-nm membrane filtrate was free of viable cells.

Serological tests. Growth inhibition and plate immunofluorescent tests, which were performed with antisera or conjugates prepared to the mycoplasmas and acholeplasmas listed in Table 1 , indicated that strain ELCN-1 ${ }^{\mathrm{T}}$ was not related serologically to previously described species in the two genera or to a group of 18 unclassified, nonhelical, sterol-requiring mollicutes that probably represent putative new species in the genus Mycoplasma.

Genome size and DNA base composition. The renaturation kinetics of strain ELCN-1 ${ }^{\mathrm{T}}$ DNA indicated that the genome molecular weight of the organism was approximately $585 \times$ $10^{6}$ (average of five determinations [504, 525, 606, 621, and 669 megadaltons]). The values for the base composition (guanine-plus-cytosine content) of the DNA of strain ELCN$1^{\mathrm{T}}$ were $27.5,27.3$, and $27.9 \mathrm{~mol} \%$ for the buoyant density, melting temperature, and high-pressure liquid chromatography techniques, respectively.

Habitat. The single strain described here was isolated directly from the hemolymph of the firefly beetle $E$. corrusca. Most mollicutes cultivated from insects have been isolated from guts $(5,6,18,30,32)$; these organisms are rarely if ever pathogenic. Certain mollicutes that establish natural infections in insect hemolymphs, such as Spiroplasma melliferum (7) and Spiroplasma apis (24), eventually kill their hosts. Whether strain ELCN-1 ${ }^{\mathrm{T}}$ is pathogenic for firefly beetles or other insects has not been determined. Occurrence of the organism in the hemolymph suggests that the relationship of strain ELCN-1 ${ }^{\mathrm{T}}$ and its insect host may be specific and unique. Additional isolations of organisms related to strain ELCN-1 ${ }^{\mathrm{T}}$ will be required to confirm this suspected specificity.

Little information is currently available on the frequency of infection of these newly recognized, nonhelical, sterolrequiring mycoplasmas in their insect hosts. Current data suggest that acholeplasmas occur much more frequently than mycoplasmas in the gut contents of insects (32), but this observation may reflect a bias induced by the insect hosts examined. However, at least six other nonhelical, sterolrequiring mollicutes have been isolated from insect or plant sources by other investigators (see review in reference 30 ).

Two previous reports of the isolation of Mycoplasma species from arthropods should also be noted. In one report, Shifrine and colleagues (27) documented the isolation of Mycoplasma mycoides subsp. mycoides from ticks collected on cattle with contagious bovine pleuropneumonia. However, the authors could not demonstrate transmission of the bovine disease with mycoplasma-infected ticks. More recently, Cottew and Yeats (10) reported the occurrence of other Mycoplasma species in mites found in the ears of clinically normal goats and suggested that these infected arthropods might represent an important reservoir for subsequent mycoplasmal infection in goats.

The properties described here for strain ELCN $-1^{\mathrm{T}}$ fulfill the essential criteria (19) for species in the class Mollicutes, including the absence of a cell wall, filterability, lack of reversion to walled bacteria when organisms are grown in antibiotic-free media, penicillin resistance, and production

TABLE 2. Growth response of strain ELCN-1 ${ }^{\mathrm{T}}$ to cholesterol

\begin{tabular}{lcc}
\hline $\begin{array}{c}\text { Supplement(s) added to } \\
\text { serum-free base medium }\end{array}$ & $\begin{array}{c}\text { Cholesterol } \\
\text { concn } \\
(\mu \mathrm{g} / \mathrm{ml})\end{array}$ & $\begin{array}{c}\text { Amt of } \\
\text { protein } \\
(\mathrm{mg} / 100 \mathrm{ml})\end{array}$ \\
\hline 17\% fetal bovine serum (control) & 0 & 2.80 \\
No supplement & 0 & $\mathrm{IG}^{a}$ \\
$1 \%$ albumin, $0.01 \%$ Tween 80 , and & 0 & $\mathrm{IG}$ \\
$10 \mu \mathrm{g}$ of palmitic acid per ml & 1 & $\mathrm{IG}$ \\
& 5 & 0.23 \\
& 10 & 0.90 \\
& 20 & 1.98 \\
\hline
\end{tabular}

${ }^{a}$ IG, Insufficient growth. 
of typical colony forms on agar. The growth requirement for sterol or serum and the lack of helicity place this organism in the family Mycoplasmataceae. The inability of strain ELCN $-1^{\mathrm{T}}$ to hydrolyze urea mandates its assignment to the genus Mycoplasma. Finally, a serological comparison of strain ELCN-1 ${ }^{\mathrm{T}}$ with an extensive collection of all previously described Mycoplasma species and with other unclassified strains that probably represent new species in the genus Mycoplasma demonstrated that the new insect isolate is unrelated to other organisms in the genus. Therefore, we propose the name Mycoplasma ellychniae for strain ELCN$1^{T}$ and similar organisms. The taxonomic description below summarizes the properties of the species.

Mycoplasma ellychniae sp. nov. Mycoplasma ellychniae (el.lych'ni.ae. N.L. n. Ellychnia, a genus of firefly beetles; N.L. gen. n. ellychniae, of Ellychnia, from which the organism was first isolated). Cells are nonhelical, pleomorphic filaments, with some branching; small coccoid forms (varying in diameter from 200 to $300 \mathrm{~nm}$ ) also occur. Cells lack true cell walls. Nonmotile. Colonies on solid medium containing $0.8 \%$ Noble agar usually have the appearance of fried eggs. Chemoorganotroph. Acid produced from glucose. Does not hydrolyze arginine or urea. Film and spot reaction negative.

Does not hemadsorb guinea pig erythrocytes.

Cholesterol or serum is required for growth.

Temperature range for growth, 18 to $32^{\circ} \mathrm{C}$, with optimum growth at $30^{\circ} \mathrm{C}$.

Serologically distinct from previously described $\mathrm{Myco}$ plasma species. Isolated from the hemolymph of the firefly beetle $E$. corrusca. Pathogenicity for insects has not been determined.

The genome averages 585 megadaltons. The guanineplus-cytosine content of the DNA is $27.5 \pm 1 \mathrm{~mol} \%$, as determined by the buoyant density method.

The type strain is strain ELCN-1 (= ATCC 43707).

\section{LITERATURE CITED}

1. Aluotto, B. B., R. G. Wittler, C. O. Williams, and J. E. Faber. 1970. Standardized bacteriologic techniques for characterization of Mycoplasma species. Int. J. Syst. Bacteriol. 20:35-58.

2. Carle, P., and J. M. Bovè. 1983. Genome size determination. Methods Mycoplasmol. 1:309-311.

3. Carle, P., C. Saillard, and J. M. Bové. 1983. DNA extraction and purification. Methods Mycoplasmol. 1:295-299.

4. Carle, P., C. Saillard, and J. M. Bové. 1983. Determination of guanine plus cytosine content of DNA. Methods Mycoplasmol. 1:301-308.

5. Clark, T. B. 1982. Spiroplasmas: diversity of arthropod reservoirs and host-parasite relationships. Science 217:57-59.

6. Clark, T. B., J. G. Tully, D. L. Rose, R. Henegar, and R. F. Whitcomb. 1986. Acholeplasmas and similar nonsterol-requiring mollicutes from insects: missing link in microbial ecology. Curr. Microbiol. 13:11-16.

7. Clark, T. B., R. F. Whitcomb, J. G. Tully, C. Mouches, C. Saillard, J. M. Bové, H. Wróblewski, P. Carle, D. L. Rose, and D. L. Williamson. 1985. Spiroplasma melliferum $\mathrm{sp}$. nov., a new species from the honeybee (Apis mellifera). Int. J. Syst. Bacteriol. 35:296-308

8. Clyde, W. A., Jr. 1983. Growth inhibition tests. Methods Mycoplasmol. 1:405-410.

9. Cole, R. M., J. G. Tully, T. J. Popkin, and J. M. Bové. 1973. Ultrastructure of the agent of citrus "stubborn disease." J. Bacteriol. 115:367-386.

10. Cottew, G. S., and F. R. Yeats. 1982. Mycoplasmas and mites in the ears of clinically normal goats. Aust. J. Vet. Sci. 59:77-81.

11. Daniels, M. J., P. G. Markham, B. M. Meddins, A. K. Plaskitt, R. Townsend, and M. Bar-Joseph. 1973. Axenic culture of a plant pathogenic spiroplasma. Nature (London) 244:523-524.

12. Doi, Y., M. Teranaka, K. Yora, and H. Asuyama. 1967. Mycoplasma- or PLT group-like microorganisms found in the phloem elements of plants infected with mulberry dwarf, potato witches' broom, aster yellows, or Paulownia witches' broom. Ann. Phytopathol. Soc. Jpn. 33:259-266.

13. Eden-Green, S., and J. G. Tully. 1979. Isolation of Acholeplasma spp. from coconut palms affected by lethal yellowing disease in Jamaica. Curr. Microbiol. 2:311-316.

14. Edward, D. G. ff. 1947. A selective medium for pleuropneumonia-like organisms. J. Gen. Microbiol. 1:238-243.

15. Freundt, E. A. 1983. Film and spot production. Methods Mycoplasmol. 1:373-374.

16. Gardella, R. S., and R. A. Del Giudice. 1983. Hemagglutination, hemadsorption, and hemolysis. Methods Mycoplasmol. 1:379384.

17. Gardella, R. S., R. A. Del Giudice, and J. G. Tully. 1983. Immunofluorescence. Methods Mycoplasmol. 1:431-439.

18. Hackett, K. J., and T. B. Clark. 1989. The ecology of spiroplasmas, p. 113-199. In R. F. Whitcomb and J. G. Tully (ed.), The mycoplasmas, vol. 5. Academic Press, Inc., New York.

19. International Committee on Systematic Bacteriology Subcommittee on the Taxonomy of Mollicutes. 1979. Proposal of minimal standards for descriptions of new species of the class Mollicutes. Int. J. Syst. Bacteriol. 29:172-180.

20. Markham, P. G., T. B. Clark, and R. F. Whitcomb. 1983. Culture techniques for spiroplasmas from arthropods. Methods Mycoplasmol. 2:217-223.

21. McCoy, R. E., H. G. Basham, J. G. Tully, D. L. Rose, P. Carle, and J. M. Bové. 1984. Acholeplasma florum: a new species isolated from plants. Int. J. Syst. Bacteriol. 34:11-15.

22. McCoy, R. E., A. Caudwell, C. J. Chang, T. A. Chen, L. N. Chiykowski, M. T. Cousin, J. L. Dale, G. T. N. de Leeuw, D. A. Golino, K. J. Hackett, B. C. Kirkpatrick, R. Marwitz, H. Petzold, R. C. Sinha, M. Sugiura, R. F. Whitcomb, I. L. Yang, B. M. Zhu, and E. Seemüller. 1989. Plant diseases associated with mycoplasma-like organisms, p. 545-640. In R. F. Whitcomb and J. G. Tully (ed.), The mycoplasmas, vol. 5. Academic Press, Inc., New York.

23. McCoy, R. E., D. S. Williams, and D. L. Thomas. 1979. Isolation of mycoplasmas from flowers, p. 75-80. In R. E. McCoy and H. $\mathrm{Su}$ (ed.), Proceedings of the Republic of China-United States Cooperative Science Seminar, Symposium Series 1. National Science Council, Taipai, Taiwan.

24. Mouches, C., J. M. Bové, J. G. Tully, D. L. Rose, R. E. McCoy, P. Carle-Junca, M. Garnier, and C. Saillard. 1983. Spiroplasma apis, a new species from the honey bee (Apis mellifera). Ann. Inst. Pasteur (Paris) 134A:383-397.

25. Razin, S., and J. G. Tully. 1970. Cholesterol requirements of mycoplasmas. J. Bacteriol. 102:306-310.

26. Saglio, P., M. L'Hospital, D. Laflèche, G. Dupont, J. M. Bové, J. G. Tully, and E. A. Freundt. 1973. Spiroplasma citri gen. and sp. n.: a mycoplasma-like organism associated with "stubborn" disease of citrus. Int. J. Syst. Bacteriol. 23:191-204.

27. Shifrine, M., K. P. Bailey, and S. S. Stone. 1972. Contagious bovine pleuropneumonia: isolation of Mycoplasma mycoides, var. mycoides from ticks collected from infected cattle and infection attempts using these ticks. Bull. Epizoot. Dis. Afr. (Spec. Issue) 20:43-45.

28. Tully, J. G. 1983. Cloning and filtration techniques for mycoplasmas. Methods Mycoplasmol. 1:173-177.

29. Tully, J. G. 1984. The family Acholeplasmataceae, genus Acholeplasma, p. 781-787. In N. R. Krieg and J. M. Holt (ed.), Bergey's manual of systematic bacteriology, vol. 1. The Williams \& Wilkins Co., Baltimore.

30. Tully, J. G. 1989. Class Mollicutes: new perspectives from plant and arthropod studies, p. 1-31. In R. F. Whitcomb and J. G. Tully (ed.), The mycoplasmas, vol. 5. Academic Press, Inc., New York.

31. Tully, J. G., D. L. Rose, P. Carle, J. M. Bové, K. J. Hackett, and 
R. F. Whitcomb. 1988. Acholeplasma entomophilum sp. nov. from gut contents of a wide range of host insects. Int. J. Syst. Bacteriol. 38:164-167.

32. Tully, J. G., D. L. Rose, R. F. Whitcomb, K. J. Hackett, T. B. Clark, R. B. Henegar, E. Clark, P. Carle, and J. M. Bové. 1987. Characterization of some new insect-derived acholeplasmas.
Isr. J. Med. Sci. 23:699-703.

33. Whitcomb, R. F. 1983. Culture media for spiroplasmas. Methods Mycoplasmol. 1:147-158.

34. Whitcomb, R. F. 1989. Biology of Spiroplasma kunkelii, p. 487-544. In R. F. Whitcomb and J. G. Tully (ed.), The mycoplasmas, vol. 5. Academic Press, Inc., New York. 